\title{
THE EFFECTS OF INTERNATIONAL MONETARY DEVELOPMENTS ON CAPITAL MOVEMENTS
}

\author{
Peter B. Clark*
}

\section{INTRODUCTION}

In the past two years there have been significant changes in the international monetary system. The recent upheavals in the gold and foreign exchange markets began with the devaluation of the British pound in November 1967. This event caused people to question the permanence of the price of $\$ 35$ per ounce for gold and thereby sparked large-scale purchases of the metal in London and other markets. At that time the gold pool countries (the United States, the United Kingdom, Belgium, Germany, Italy, the Netherlands, and Switzerland) maintained the price by supplying the difference between total private demand and current gold output. The price-stabilization strategy, originally designed to reduce speculative purchases, led to a depletion of monetary gold stocks of nearly $\$ 3.0$ billion between November I967 and March I968. Since this strategy was clearly not working, the gold pool countries agreed in March of last year that they would no longer stabilize the free market price of gold. They also agreed that all of the future output of gold should be directed to the private market, thereby fixing the stock of monetary gold at the then existing level. Thus was born a major innovation in the world financial system: a two-tier gold price arrangement. Gold continues to be exchanged between central banks at the rate of $\$ 35$ per ounce, but the price at which it is available on the private market is determined by the forces of supply and demand.

This step in the direction of demonetizing gold, namely an agreement to refrain from making any additions to the world's monetary gold stock, was made possible by the prospective establishment of a special borrowing facility in the International Monetary Fund known as Special Drawing Rights. On March 30, 1968, after four years of negotiations, the major western countries, with France dissenting, finally approved an arrangement which would create a new reserve asset. Therefore, although discussions concerning international monetary reform had been going on for some time, it was nevertheless somewhat fortuitous that the decision to downgrade the role of gold as a reserve asset coincided with the decision to create an alternative source of international reserves.

The devaluation of the British pound, which initiated the series of events described above, was undertaken as a solution to a persistent balance-of-payments deficit. Since it was clear that any change in par value that might occur would be a devaluation, the payments deficit generated large speculative capital movements against the pound.

* Ph.D. I967, Massachusetts Institute of Technology. Assistant Professor of Economics, Duke University. 
This exacerbated an already precarious position and led to criticism of the fixed exchange rate system. This criticism became even more pronounced after the events of May and June 1968 in France and the German-French crisis in November. Dissatisfaction centered on the costs incurred under the par value system. First, by maintaining a fixed rate of exchange between its own currency and other currencies a country must sacrifice the attainment of domestic policy goals in order to achieve a balanced external account. Second, if the country does not undertake the costly adjustments which are necessary to avert a deficit, then devaluation becomes inevitable, bringing with it huge speculative capital movements which upset the entire international monetary system. To some observers these costs appear to be excessive, and the recent crises have led to serious discussion of the possibility of allowing balance-of-payments adjustment to take place by means of greater flexibility in exchange rates.

The developments in the international monetary system have had primarily a short-run effect on capital movements. Balance-of-payments deficits in the United States, the United Kingdom, and France induced large speculative short-term capital outflows and encouraged the expectation that the price of gold would be increased. However, the structure of the present system is closely related to other, more enduring types of capital flows, viz., U.S. investment abroad and the increase in foreign official holdings of U.S. dollars. This relationship, which is based on the role of the dollar in the system, will be described in some detail in section I of this article.

These recent developments contain the seeds of future changes which may have a long-term impact on foreign investment. In section II, I shall look at the possible effects of the deliberate creation of international reserves in the form of Special Drawing Rights. With larger reserves, countries can afford to relax restrictions on the purchase of foreign goods and assets. In addition, if they were previously forced to pursue a deflationary policy because of a payments deficit, then with an addition to their stock of reserves they might feel inclined to follow more expansionary monetary and fiscal policies. Such policies will influence the determinants of capital flows, the precise effect depending on the particular type of policy response.

For example, if government expenditures increase while monetary policy remains unchanged, there would be expansion in income and a rise in interest rates. The larger profits generated by the expansion would probably lead to larger capital inflow or reduced capital outflow, as would the rise in interest rates. However, if the increased government expenditures are accompanied by an expansionary monetary policy, then interest rates might not rise at all, and in fact they might even decline. In this case it is not clear whether there would be a capital inflow or outflow. Only if one makes specific assumptions about the changes in monetary and fiscal policies caused by the increased reserves is it possible to say anything definite about the response in capital movements. 
The growing dissatisfaction with fixed exchange rates has prompted increased interest and discussion concerning some form of flexibility in exchange rates. ${ }^{1}$ There is more or less general agreement that the costs of adjusting to a balance-of-payments disturbance will be lower if exchange rates are allowed to fluctuate by more than the present one per cent around the par value. The main objection to greater flexibility is that such a system will increase the risks associated with international transactions. Businessmen will presumably be much less sure what the value in domestic currency of their foreign sales will be. They may eliminate the exchange risk by selling the proceeds of their foreign sales in the forward exchange market, but such hedging may become very costly. Similarly, an investor contemplating the purchase of a foreign -asset may be deterred by the fact that the exchange rate at which he will convert his principal and interest into domestic currency cannot be predicted with certainty. It is true that short-term investments can be hedged in the forward market, but in general this is not possible for assets which are held for more than two years. If in fact international trade and investment will be reduced because of the increased uncertainty associated with international transactions, then a flexible exchange rate system entails a cost in the form of a reduction in the gains from the exchange of both goods and assets.

But this is only part of the effect of greater exchange rate flexibility on capital Hows. Another equally important aspect is the extent to which controls on capital movements will be dismantled. When the exchange rate is permitted to fluctuate, demand and supply for foreign currency is equilibrated by variation in the price of foreign exchange. It is therefore no longer necessary either to hold international reserves (which accommodated excess demand at a fixed exchange rate) or to eliminate the excess demand by restrictions on payments abroad. In addition, a flexible exchange rate will allow a country to pursue domestic policy goals more independently of balance-of-payments considerations than would be the case with a fixed rate.

Capital movements will therefore be affected simultaneously by all three consequences of a flexible exchange rate: the change in domestic policies, the reduction in controls, and the possible increase in uncertainty associated with international transactions. To explore further the implications of a flexible exchange rate system on capital movements would, however, be beyond the scope of this paper. ${ }^{2}$

\footnotetext{
${ }^{1}$ For example, in its 1969 annual report, the Council of Economic Advisers has one section entitled "Exchange Rate Adjustments." See 1969 CEA ANN. REP. 145-49. In' addition, a current member of the Council, Hendrik S. Houthakker, has recently advocated widening the permitted margins within which exchange rates may fluctuate from the present I\% either side of par to 2 or $3 \%$. N. Y. Times, March 24, 1969, at 63. Finally, the U.S. Chamber of Commerce has for the first time urged that serious study be given to more flexible exchange rates. N.Y. Times, Feb. 28, I969, at 51 .

${ }^{2}$ For two recent discussions of this topic, see L. Yeager, International Monetary Relations ch. 12 (1966), and A. Lanyi, The Case for Flonting Exchange Rates Reconsidered (Princeton University Essays in Int'l Finance No. 72, 1969).
} 


\section{Capital Movements and the International Monetary System}

To explain the relationship between developments in the international monetary system and capital movements it is first necessary to describe the central role of the U.S. dollar in this system. The importance of the dollar stems from the fact that it serves as an international reserve asset. Part of the reason why foreign central banks and monetary authorities hold dollars is that, at least in principle, the U.S. Treasury guarantees that these holdings can be converted into gold at the fixed rate of $\$ 35$ per ounce. Probably more important in explaining the dollar's appeal are the following facts: it has always been freely convertible into other currencies, the risk of devaluation, at least in the past, has been very low, and, finally, the variety and quantity of goods which can be purchased in this country are greater than anywhere else in the world.

These factors were especially important in the I940s and I950s when the United States was the only source of a large number of products and when our gold stock exceeded our liabilities to foreigners by a wide margin. Because of their complete faith in the stability of our currency, central banks began to hold dollars rather than gold when the United States ran a payments deficit during the I950s. Since the dollar was as good as gold, there was no reason for holding the shiny, barren metal when one could earn interest by buying short-term bonds, such as U.S. Treasury bills. Hence the fact that New York City provides a very broad money market, making the buying and selling of bonds very convenient and inexpensive, further enhanced the attractiveness of the dollar. In addition, the mere fact that most countries maintain the external value of their currency by buying and selling dollars in the foreign exchange market means that the dollar is a natural candidate for reserve currency status.

This special status has endowed the United States with the privilege of being able to finance the excess of its international payments over receipts by issuing its own liabilities to foreigners (which constitutes a capital inflow into the United States), rather than by drawing on its gold stock. When foreign central banks finance our balance-of-payments deficit by buying Treasury bills, for example, they are essentially extending us short-term loans. This has allowed us to spend more abroad for goods and services, for foreign investment, and for foreign economic and military aid than otherwise would have been possible.

The use of the dollar as a reserve asset has therefore been a boon to both the United States and the rest of the world. The United States could make payments to foreigners with its own currency, rather than use its reserves, and the countries which chose dollars rather than gold acquired an asset which was both more convenient to use and more valuable insofar as the interest earnings outweighed the risk of devaluation. Most important of all, the U.S. deficit between $195^{\circ}$ and $x 969$ has been 
a powerful engine for the creation of international liquidity. It has provided a crucial supplement to the gold in the coffers of central banks. Between $x 95^{\circ}$ and the end of 1966 , the stock of monetary gold rose from $\$ 35$ billion to slightly over $\$ 43$ billion, or an increase of twenty-three per cent. Dollar reserves increased from $\$ 4$ billion to $\$ 13^{1 / 2}$ billion, or over 200 per cent. There is little doubt that, by adding considerably to world reserves, the U.S. payments deficit helped grease the wheels of international trade and finance.

Now as long as the dollar was unquestioned as a reserve asset, there was no need to limit the demand in this country for foreign currency to be used for acquiring assets abroad. Therefore, although it is a basic principle of balance-of-payments analysis that a particular item in the payments accounts cannot be singled out as the cause of a surplus or deficit, it nevertheless is reasonable to assume that at least a certain proportion of the U.S. capital outflow was made possible by the willingness of foreign monetary authorities to hold dollars as reserves. If there had been a preference for gold rather than dollars, the United States would have had to adopt measures which would have restricted the demand for foreign exchange. In fact, we have seen over the past few years that as the dollar has become less attractive as a reserve asset, the United States, instead of adopting general deflationary monetary and fiscal policies designed to reduce the demand for foreign goods and services, has instead used ad hoc measures to cut down the demand for foreign assets. Hence, if the dollar had not had the status of an international reserve asset, restrictions on U.S. foreign investments would no doubt have been imposed much earlier.

However, it is not clear that the refusal of foreigners to hold dollars as reserves would necessarily have resulted in a lower rate of increase in assets abroad. First of all, the restrictions themselves may be ineffective, as the interest equalization tax of 1963 and the voluntary credit restraint program of 1964 appear to have been. As Table I indicates, U.S. private investment abroad did not decline after these restraints were imposed; of course, it is possible that capital outflows would have been much larger than they in fact were. In any event, capital controls are notoriously difficult to police, and, furthermore, restrictions on the movement of capital abroad have encouraged American firms to substitute foreign for domestic funds. Even if such controls were effective in reducing the balance-of-payments impact of foreign investment, the use of funds generated abroad (retained earnings, depreciation allowances, and foreign borrowings) could result in a net increase in U.S. assets abroad. ${ }^{3}$ In sum, then, it is quite possible that even if the dollar were not a reserve currency, and all other items in the balance of payments remained the same, the rate of

\footnotetext{
${ }^{8}$ Compare the following remark: "Thus, while use of foreign-borrowed funds offset a large portion of the balance of payments impact of investment activities, the actual transfers of capital for direct investment purposes were not reduced, and the Foreign Direct Investment Program appears to have had little or no adverse effect on the scope of investment activities by foreign affiliatcs." Nelson \& Lechter, The Balance of Payments in 1968, 49 Survey OF Current Business, Jan. 1969, at 35.
} 
TABLE I

U.S. and Foreign Capital Movements, 1950-I968

(millions of dollars)

\begin{tabular}{|c|c|c|c|c|}
\hline \multirow[b]{2}{*}{ Year } & \multicolumn{3}{|c|}{ U.S. private capital, net } & \multirow[b]{2}{*}{$\begin{array}{l}\text { Total foreign } \\
\text { capital, net }\end{array}$} \\
\hline & $\begin{array}{c}\text { Direct } \\
\text { Investment }\end{array}$ & $\begin{array}{c}\text { Other } \\
\text { long-term }\end{array}$ & Short-term & \\
\hline 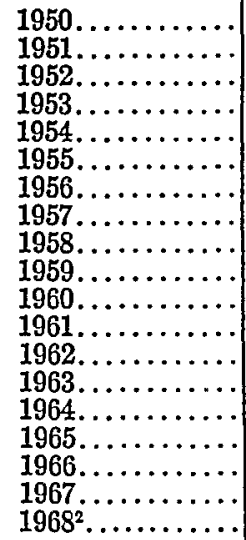 & $\begin{array}{r}-621 \\
-508 \\
-852 \\
-735 \\
-667 \\
-823 \\
-1,951 \\
-2,442 \\
-1,181 \\
-1,372 \\
-1,674 \\
-1,598 \\
-1,654 \\
-1,976 \\
-2,328 \\
-3,468 \\
-3,623 \\
-3,020 \\
-3,348\end{array}$ & $\begin{array}{r}-495 \\
-437 \\
-214 \\
185 \\
-320 \\
-241 \\
-603 \\
-859 \\
-1,444 \\
-926 \\
-855 \\
-1,025 \\
-1,227 \\
-1,698 \\
-2,103 \\
-1,079 \\
-256 \\
-1,270 \\
-630\end{array}$ & $\begin{array}{r}-149 \\
-103 \\
-94 \\
167 \\
-635 \\
-191 \\
-517 \\
-276 \\
-311 \\
-77 \\
-1,349 \\
-1,556 \\
-546 \\
-785 \\
-2,147 \\
753 \\
-418 \\
-1,214 \\
-1,280\end{array}$ & $\begin{array}{r}181 \\
540 \\
52 \\
146 \\
249 \\
297 \\
615 \\
545 \\
186 \\
736 \\
364 \\
702 \\
1,026 \\
690 \\
689 \\
270 \\
2,531 \\
3,185 \\
7,448\end{array}$ \\
\hline
\end{tabular}

Source: Coovron of Economic Advisens, Annual Report table B-84 at 325 (1969).

Note. A minus sign denotes a capital outflow and a plus sign a capital inflow.

1. Includes certain special government transactions.

2. Average of the first three quarters on a seasonally adjusted annual rate basis.

foreign investment would not have changed appreciably despite the imposition of capital controls.

There is an additional reason why capital flows might have continued at the same rate, as in fact occurred. If foreign central banks refrained from accumulating dollar assets because they did not wish to increase their reserves, then it would be unwarranted to assume that the other items in the balance of payments would remain unchanged. The smaller surpluses (or larger deficits) of other countries would be matched by a smaller U.S. payments deficit. This implies that there would be larger positive items in the U.S. balance of payments, e.g., a larger surplus in the current account, which would finance the acquisition of assets abroad. In other words, the foreign exchange required for investment abroad would be provided by larger autonomous U.S. foreign exchange earnings instead of by central banks. ${ }^{4}$ With the balance of payments more or less in equilibrium, there would be no reason to impose controls on capital movements. Hence it is quite conceivable that the

\footnotetext{
'This line of reasoning assumes that the determinants of foreign investment would remain unchanged from one situation to another. This may be an inappropriate assumption, since the decision not to accumulate reserves may have an effect on the factors affecting capital movements, e.g., the level of income and the interest rate. The discussion in section $I I$ of this paper bears on this point.
} 
magnitude of U.S. foreign investment would not have changed a great deal if the dollar had not served as an international reserve asset.

Implicit in the above discussion is the view that the growing demand for reserves on the part of the rest of the world results in a deficit in the U.S. balance of payments. In the absence of any other significant source of international liquidity, countries have had to run payments surpluses vis-à-vis the United States and in so doing have satisfied their demand for reserves by raiding the U.S. gold stock and/or by holding dollars. ${ }^{5}$ If other countries wish to accumulate reserves, and if alternative reserve assets are not readily available, then it will turn out that they will acquire dollars. The United States, in this view, is therefore not running a deficit in any meaningful economic sense. On the contrary, it is providing an important service to the world economy. Hence, if this view is correct, it is senseless for the United States to impose restrictions on capital movements, since any reduction in the supply of dollars will cause balance-of-payments adjustments in other countries which will eventually reduce the autonomous supply of foreign exchange.

A somewhat similar approach has been developed by Professor Charles Kindleberger. ${ }^{6}$ His contention is that the United States plays the role of a financial intermediary for the world economy. This role arises from the different liquidity preferences in the United States and abroad. Europeans, having experienced high rates of inflation, wars, and general economic uncertainty, can be induced to hold long-term, illiquid assets only if they are given a high rate of return. Americans, on the other hand, have not had such unfortunate experiences with long-term investments, and therefore do not require such a large incentive to part with liquid assets as do Europeans. On the assumption that desired savings equal desired investment in both areas, the difference in liquidity preferences implies that long-term interest rates will be higher in Europe than in the United States and short-term interest rates higher in the United States than in Europe.

If capital markets are not restricted, the United States will lend long-term funds to Europe and in exchange borrow short-term funds. The United States thus provides European investors with funds at lower cost than is available domestically and can pay higher interest rates on the liquid assets held directly or indirectly by European savers. Therefore the U.S. balance-of-payments deficit, manifested by an increase in liquid liabilities to foreigners equal to the excess of capital outflow and govern-

\footnotetext{
"Additions to monetary gold, as has already been mentioned, have been rather small. The International Monetary Fund has not provided large increments in international liquidity because members' quotas (which indicate the amount of convertible currency a country can borrow) are raised only infrequently and because, at least until recently, the Fund has been very strict in its lending to members. The point mentioned in this paragraph has recently been made by Robert A. Mundell in a preliminary version of a paper presented to the Annual Meeting of the American Economic Association, Dec. 30, 1968, Chicago, Ill., entitled "Real Gold, Dollars and Paper Gold."

'See C. Kindleberger, Balance-of-Payments Deficits and the International Market for Liouidiry (Princeton University Essays in Int'l Finance No. 46, 1965); see also Depres, Kindleberger \& Salant, The Dollar and World Liquidity-A Minority View, 218 THE Economisr 536 (1966); Laffer, The U.S. Balance of Payments-A Financial Center View, in this symposium, p. 33 .
} 
ment spending abroad over the current account surplus, does not represent a disequilibrium situation. It is providing a real service to the world economy, and all attempts to eliminate it by restrictions on U.S. capital flows abroad are, in Kindleberger's view, extremely misguided and can only reduce world welfare.

This point of view, while very appealing as an economic explanation of the U.S. payments deficit, has yet to be supported with empirical evidence. It is nevertheless an important contribution because it points out the interrelationships between capital movements, the U.S. payments deficit, and the international monetary system. Needless to say, this approach is not accepted by either American or European government officials. They regard the payments deficit as a potentially dangerous situation which must be eliminated as soon as possible. At one time the European objection was based partly on dislike and fear of American investment in Europe, and, by holding dollars in their reserves, central bankers were in effect supplying foreign exchange which could be used for investment purposes.

The more important long-run objection is that the U.S. deficit constitutes an extremely grave threat to the entire international monetary system. The willingness of foreign central banks to hold dollars in their reserves is to a large extent determined by their faith in their ability to convert dollars into gold at the rate of $\$ 35$ per ounce. One can argue, as Kindleberger does, that if central bankers were rational, they would prefer holding dollars to holding gold. ${ }^{7}$ Nevertheless, it remains a fact that this faith is eroded when the U.S. gold stock declines and claims against that stock increase. The U.S. deficit, which has been financed primarily by a reduction in our gold stock and an increase in our liabilities to foreign monetary authorities, has led to doubts about the ability of the U.S. Treasury to honor its conversion guarantee. In addition, there is speculation that in order to honor its guarantee the United States may be forced to raise the price of gold, which would of course mean that those who held dollars would lose out on the windfall gain. It is in order to prevent a loss of confidence in the dollar-and the stampede to buy gold and the attendant confusion and disruption in the international monetary system which this would entail-that government officials are urging that the U.S. balance-of-payments deficit be reduced. And, as many of the other papers in this symposium describe in great detail, the burden of improvement has been placed primarily on the capital account.

If the United States is successful in eliminating its payments deficit, then an important source of international reserves will also disappear. As was mentioned in the introduction, the decision of the gold pool countries not to stabilize the free market price of gold was accompanied by a commitment not to add any more gold to their reserves. Since most other countries have also made this commitment, the free world may be in the position of not having a source of supply of additional inter-

\footnotetext{
' See in particular C. KIndleberger, International Monetary ARrangements (English, Scottish and Australian Bank Research Lecture, I966).
} 
national liquidity. ${ }^{8}$ However, as already indicated above, a plan to establish a new international monetary facility was presented in May Ig68 to members of the International Monetary Fund (IMF) for their approval. There appears little doubt that this amendment to the Fund's Articles of Agreement will be accepted. Once this is accomplished, however, there still remains the task of implementation. A separate vote requiring a majority of eighty-five per cent of the total voting power is necessary for the activation of the scheme, and the Common Market countries, with a combined voting power exceeding fifteen per cent, can veto the implementation of this new source of liquidity. Hence there is one more obstacle to be overcome before this substitute for gold and dollars becomes a reality.

This new reserve facility at the Fund differs considerably from the existing drawing rights. As presently set up, the Fund consists of a kind of warehouse of gold and currencies contributed by member countries. When a country has a payments deficit, it can supplement its own reserves by purchasing the foreign exchange it needs from the warehouse, i.e., the Fund, with its own currency. The amount a country can borrow is determined by its quota, which is its contribution of gold and own currency to the Fund, and repayment must be made within three to five years.

The new Special Drawing Rights, or SDRs, are based on a different principle, namely, that the claim or asset represented by the Drawing Right is itself transferable among member countries. If a country has a deficit and wishes to use its SDR, it has the right to present it to any participating country and receive in return the currency of that country. Thus the SDRs will be internationally acceptable assets which can be exchanged for the foreign exchange needed to finance a payments deficit. This claim can be used without any strings for balance-of-payments purposes, the only proviso being that over the first period of operation no country's average net use of its SDRs may exceed thirty per cent of the total drawing right allocated to it. Since seventy per cent of the drawing right is essentially a free good, countries are obligated to accept SDRs from other participants only up to twice the amount of SDRs allocated to them. This is to reassure potential creditor countries that they will not be left holding a bag of worthless assets.

While the total amount of this new reserve asset must still be agreed upon, there has been talk of allocating \$I billion of SDRs every year for five years. A country's share in this total will be determined by its quota in the IMF. This addition to the stock of international liquidity is certainly to be welcomed in the light of an actual decline in world reserves in the past year. With more reserves, countries will not have to incur the costs of rapid adjustment to balance of payments disturbances.

\footnotetext{
${ }^{8}$ Due to large sales of gold in the London market designed to stabilize the free market price, total reserves (gold, convertible foreign exchange, and reserve positions in the Fund) of IMF member countries actually declined from $\$ 55.182$ bilion at the end of 1967 to $\$ 52.850$ in January 1969.22 INT'L Financial. Statistics, March r969, at i4.
} 
II

\section{The Effects of an Increase in Reserves on Capital Movements}

Since it is fairly certain that additional international reserves in the form of Special Drawing Rights will be forthcoming, it is important to assess the effects of this innovation in the world monetary system on capital movements. With respect to the United States in particular, it should first be pointed out that some members of the IMF (especially the Common Market countries) have indicated that they will not approve the implementation of the SDRs unless the United States corrects its payments deficit. They fear that this country will simply use its allocation of new reserves to finance its continuing payments imbalance and thereby further delay the corrections needed to achieve equilibrium. If this attitude persists, then it is possible that no agreement will be reached on implementing the SDR scheme.

It is doubtful, however, that the desire to obstruct the creation of new reserves is as strong as it once was. First of all, the U.S. payments deficit has improved dramatically in the past year, moving from a deficit of $\$ 3.57$ billion in 1967 to a surplus of $\$ 187$ million in $1968 .^{\circ}$ This unexpected turnabout was due primarily to an exceptionally large foreign capital inflow (see Table I above). Although the payments surplus is not predicted to continue in 1969 , the United States can nevertheless point to the past improvement as an indication that the situation is getting better. Second, the French balance-of-payments crisis has no doubt led France to reconsider its opposition to the creation of international reserves. More generally, the FrenchGerman exchange crisis of November 1968 , which was dominated by massive speculative short-term capital movements, has demonstrated that the existing stock of reserves is by no means sufficient to cope with such large balance-of-payments disturbances. Hence it seems reasonable to assume that when the IMF meets in September 1969 , some SDRs will in fact be allocated.

In describing the possible effects of larger reserves on international capital movements, it will be helpful to first outline the analytic framework developed below. The basic point is that an increment in reserves will have both direct and indirect effects on the determinants of foreign investment. The direct effect refers to the response of the flow of capital to the relaxation of restrictions on capital movements which may accompany the increase in international liquidity. Larger reserves may also tend to make the country pursue more expansionary monetary and fiscal policies, and these induced policy changes will have an impact on important macroeconomic determinants of capital flows, such as income and interest rates. The response of foreign investment to these changed conditions is referred to as the indirect effect

\footnotetext{
${ }^{\circ}$ These figures refer to the deficit or surplus as measured on the liquidity basis, i.e., the change in U.S. reserve assets and in liquid liabilities to all foreigners. If the official settlements basis is used (change in U.S. reserves and in liquid liabilities to official monetary authorities), the figures of I967 and r 968 are a deficit of $\$ 3.405$ billion and surplus of $\$ x .659$ billion, respectively. 2r INT'L Financiar News SuRVEY, Feb. 1969 , at 50 .
} 
of larger reserves. While the direct effect can be expected to lead to an increase in assets abroad, we shall see that the indirect effect may involve either an inflow or outflow of capital.

The basic assumption of this analysis is that the policy makers are constrained by the stock of reserves they hold. Most countries try to achieve certain domestic policy goals such as full employment, a rapid rate of growth in real output, and a stable price level. These goals may themselves be mutually inconsistent, but they may also be inconsistent with the need to maintain balance-of-payments equilibrium. The reason for this is that with a fixed exchange rate, a rapid expansion in output will usually result in a payments deficit. This deficit can either be financed with reserves or it can be eliminated by restrictions on international transactions, e.g., tariffs, quotas, exchange control, and capital controls. Since most western countries also regard the elimination of restrictions on international transactions as a desirable objective, the domestic goals and the goal of an open economy may also be inconsistent. If a country has a sufficiently large stock of reserves, it can more easily attain both goals. Conversely, if its reserves are in short supply, it will have to introduce deflationary measures and/or restrictions on payments to foreigners in order to reduce any incipient balance-of-payments deficit. Therefore an increase in reserves relaxes the constraint under which domestic and foreign economic policies operate; domestic policies can become more expansionary and restrictions on international transactions can be liberalized.

The impact of this liberalization on capital movements depends on the existing level of restrictions and on relative attractiveness of foreign versus domestic investment. If the restrictions imply a complete prohibition of capital outflows and if they are effective, then any relaxation would no doubt lead to the acquisition of some assets abroad, since there will certainly be some investment opportunities which yield a higher rate of return than can be obtained at home. If the controls involve only a partial restriction on capital movements, and if investment opportunities are more attractive at home than abroad, then a liberalization of controls need not entail a greatly increased capital outflow. For example, the rate of return on foreign U.S. direct investment has declined over the past eight years and is now roughly equal to the rate of return on domestic investment. ${ }^{10}$ In addition, interest rates are at an all-time high in this country, so that there is little or no interest rate differential favoring foreign markets. Under these circumstances a relaxation of the Commerce Department's Foreign Direct Investment Program and the Federal Reserve System's voluntary credit restraint program for banks and nonbank financial institutions would probably have only a small impact.

\footnotetext{
${ }^{10}$ The yield on total U.S. direct investments abroad (earnings related to the value of investment at the beginning of the year) is reported to have been $11.0 \%$ in 1967 . Nelson \& Cutter, The International Investment Position of the United States in 1967, 48 SURvey of CURRENT BustNess, Oct. 1968, at 26. In First National Crty Bank Monthly Econ. LetTer, March 1969, at 29, an $11.0 \%$ rate of return in I967 is also reported. This finding is based on the bank's survey of the earnings of over 2000 corporations.
} 
On the other hand, if rates of return and interest rates were considerably higher abroad, any relaxation of controls would result in a large capital outflow. First, the flow of new investments abroad would increase. Second, there is likely to be refinancing at home of the borrowing abroad which was induced by the control program. This once-and-for-all reduction in the stock of liabilities to foreigners could have a significant impact on the balance of payments. In any case, the direct effect of larger reserves can be expected to be negative, i.e., an increased outflow.

The indirect effect of larger reserves on capital flows is brought about by more expansionary monetary and fiscal policies. In analyzing the impact of such policies on the determinants of foreign investment it is convenient to think in terms of a simple short-run Keynesian model. ${ }^{11}$ In such a model fiscal policy is conventionally represented by a change in government spending and monetary policy by a change in the money supply. If government expenditures increase as a result of the allocation of SDRs, then there will be a rise in the level of income because of the net addition to the spending stream. Assuming no concomitant increase in the money supply, there will also be a rise in interest rates because of the increased demand for money for transactions purposes and because the sale of bonds to finance the government spending depresses bond prices. There would be no net change in current expenditures if the demand for money were completely unresponsive to the level of the interest rate. Under this assumption the increment in government spending would cause the interest rate to rise to such an extent that investment expenditures would decline by an equal amount. Since empirical studies show that the demand for money is interest-rate elastic, we can conclude that greater government spending will in general cause income and interest rates to rise.

The impact of the money supply change will be somewhat different. In this case the rate of interest will fall, since bond prices will be bid up and individuals will hold the larger money stock only if the opportunity cost of doing, i.e., the interest rate, has declined. As long as investment expenditures are responsive to interest rate changes, the expansion in the money supply will also lead to an increase in current spending, thereby raising the level of income.

Monetary and fiscal policies can therefore be expected to have the same (positive) effect on income and different effects on the interest rate. If both types of expansionary policies are employed simultaneously, then the effect on income will a fortiori be larger and the effect on the rate of interest indeterminate.

What can we now assert about the response of capital flows to the changed conditions? Let us first assume that the factors in the rest of the world which influence foreign investment remain unchanged. It will also be helpful to distinguish between investment abroad by residents and investment in the domestic economy by for-

${ }^{11}$ The results which are described in this section were worked out analytically using a modified version of a mathematical model employed in Johnson, Some Aspects of the Theory of Economic Policy in a World of Capital Mobility, in 2 Essays IN HoNOR OF Marco FanNo 345 (T. Bagiotti ed. I966). 
eigners. Capital flows can be further subdivided by type, namely, portfolio and direct investment. I shall depart somewhat from customary usage by defining portfolio investment as that which is motivated primarily by interest rate differentials and equity investment as that determined by relative profitability. ${ }^{12}$

Where direct investment depends only on relative profitability, expansionary economic policies induced by larger reserves will tend to decrease the rate of direct investment abroad and increase the rate of direct investment at home by foreigners. This conclusion is based on the reasonable assumption that a rise in the level of income will be associated with increased profitability of investment at home relative to opportunities abroad. ${ }^{13}$ Hence a higher rate of output at home will tend to reduce the direct investment outflow (or increase the inflow) as both national and foreign firms increase their expenditures on real domestic assets. This result does not depend on whether the expansion in output stems from monetary or fiscal policy, since in either case output expands.

The effect on portfolio investment, however, is sensitive to the particular type of economic policy employed. If there is a rise in government expenditures, then interest rates will also rise. This will encourage a larger capital inflow (or smaller outflow) as residents repatriate funds invested overseas and as foreigners shift funds from other money-market centers to the domestic economy. ${ }^{14}$ The opposite effect is achieved if monetary policy is the instrument used to expand output, since the larger money supply, by reducing interest rates, will encourage a capital outflow.

The indirect effect of larger reserves on capital movements is therefore unequivocal if fiscal policy is employed: both income and interest rates are higher than they were previously, thereby attracting both portfolio and direct investment. With monetary policy the effect is ambiguous: direct investment will be induced because of the rise in output, but portfolio capital will flow abroad since interest rates at home will decline. In this case the ultimate outcome depends on the absolute magnitudes of the induced changes in income and interest rate and on the responsiveness of the two types of capital flows to their respective determinants. In addition, the effect will no doubt depend on the speed with which income and interest rates react to the change in the money supply. Since in the normal (Keynesian) course of events the change in interest rates precedes the change in income, it follows that there would first be a capital outflow which would later be reduced and possibly reversed

\footnotetext{
${ }^{12}$ This distinction is also made by Johnson. Id. at 346 . He uses the terms "income-mobility" and "interest-mobility" for what I have called direct and portfolio investment respectively.

${ }^{13}$ There is some empirical support for the view that direct investment is related to changes in income. Raymond Mikesell has found that "The rates of growth in the value of U.S. direct investment in each of the Common Market countries between 1957 and 1965 tended to follow the rank order of the rates of increase in their real G.N.P. ..." Mikesell, Decisive Factors in the Flow of American Direct Investment to Europe, 20 Economia InTernazionale, March 1967, at I4.

${ }^{14}$ Recent empirical investigations have demonstrated that international capital movements are sensitive to interest rate differentials. See, e.g., Stein, International Short Term Capital Movements, $55 \Lambda \mathrm{M}$. ECON. REV. 40 ( $x 965)$.
} 
by the income effect on direct investment. It may take a considerable amount of time before the capital inflow induced via expansionary monetary policy actually occurs: investment expenditures lag considerably behind interest rate changes, larger profits will only be realized once the multiplier effects of the higher investment spending have been worked out, and entrepreneurs will respond to the increased profitability only with a lag. Hence in comparison with fiscal policy it would appear that monetary policy induces a smaller capital inflow.

If both direct and indirect effects on capital movements are added together, the net effect due to monetary expansion will most likely be a smaller capital inflow (or larger capital outflow). With fiscal policy the combined effect is ambiguous because the factors affecting capital flows operate in different directions: the relaxation of restrictions encourages a capital outflow whereas both higher income and interest rates attract capital from abroad. Now if the allocation of reserves leads to both greater government spending and a larger money supply, then the impact on capital flows becomes even more ambiguous. The change in income will be larger than when the policy instruments were used separately, but interests rates may not rise at all, and in fact may even decline. Hence in the general case one must know not only the direction of change of the variables but also the magnitude of the change.

If conditions abroad also respond to the allocation of reserves, then it should be clear that without more knowledge it will be impossible to make predictions about the direction of induced changes in capital flows. The total effect of the reserve allocation obviously depends on the type of change in domestic economic policies and on the extent to which controls on capital movements are relaxed in all countries. However, two special cases should be briefly mentioned. First, let us assume that there is no change in domestic policies and capital controls as a result of the distribution of reserves to all countries. There may nevertheless be larger gross flows of capital between countries because of the lower risk involved in holding foreign assets. This follows from the fact that, with larger reserves, countries will be less inclined to devalue their currencies or impose restrictions on capital movements in the face of future balance-of-payments deficits. Second, assume that the increment in reserves leads to expansionary policies which leave unaltered the existing differentials in interest and profit rates. If, as seems reasonable, firms and individuals wish to diversify their holdings of real and financial assets among countries, then the rise in income will induce larger gross capital flows between countries. ${ }^{15}$ At the higher level of income, people will hold a larger stock of assets, and portfolio-balance considerations imply that part of the larger portfolio should be represented by additional holdings of foreign assets even though there has been no change in relative yields.

\footnotetext{
${ }^{18}$ For a description of the portfolio approach to international capital movements, see Grubel, Internationally Diversified Portfolios, 58 Am. Econ. Rev. 1299 (rg68). The main thrust of this approach is that by purchasing foreign assets an investor can reduce the over-all riskiness of his portfolio without any sacrifice in rate of return.
} 
Of course, if the total allocation of SDRs is rather small, such as the $\$$ r.o billion per year which has been suggested, then since each country receives only a small fraction of this equal to its quota, the immediate impact of this increase in reserves on capital flows would be imperceptible. However, it appears that the United States may ask for a sizable initial distribution during the first year that the SDRs are activated, on the order of $\$ 4.0$ to $\$ 5.0$ billion, and lesser amounts ( $\$ 1.0$ to $\$ 2.0$ billion) in later years. ${ }^{16}$ The rationale for this "front-loading" approach is to compensate for the loss of $\$ 3.0$ billion in monetary gold last year. If this quantity of reserves were allocated, then the effect on capital flows could be significant.

\footnotetext{
${ }^{16}$ N.Y. Times, March 24, r969, at 63; $i d$., March 28, I969, at 67.
} 